\title{
Histone deacetylase inhibitors in plasma cell leukemia treatment: effect of bone marrow microenvironment
}

\author{
I. BURIANOVA ${ }^{1,2,3}$, K. KUZELOVA ${ }^{1}$, O. MITROVSKY ${ }^{1,2}$, I. SPICKA ${ }^{4}$, P. STOCKBAUER ${ }^{1}$, M. ZACKOVA ${ }^{1, *}$ \\ ${ }^{1}$ Department of Proteomics, Institute of Hematology and Blood Transfusion (IHBT), Prague, Czech Republic; ${ }^{2}$ Department of Biochemistry, Faculty \\ of Science, Charles University, Prague, Czech Republic; ${ }^{3}$ Department of Clinical Biochemistry, Thomayer Hospital, Prague, Czech Republic; ${ }^{4} 1 s t$ \\ Department of Internal Medicine, Division of Hematology, General Faculty Hospital, Charles University, Prague, Czech Republic
}

*Correspondence: marketa.zackova@uhkt.cz

Received May 2, 2016 / Accepted October 22, 2016

\begin{abstract}
In the presented study we analysed the effect of histone deacetylase inhibitors (HDACi) suberoylanilide hydroxamic acid (SAHA) and valproic acid (VPA) on human plasma cell leukemia (PCL) cell line UHKT-944 in the presence of bone marrow microenvironment (BMM). For the analysis, the cells were cultured alone, with bone marrow stromal cells (BMSCs), with extracellular matrix (ECM) components or with interleukin-6, and treated with varied concentrations of SAHA and VPA for 24/48 hours. To study the effect of HDACi, we investigated cell proliferation, apoptosis, cell cycle and changes in selected signalling pathways. We found that both SAHA and VPA induced apoptosis, but had no effect on the cell cycle distribution of UHKT-944 cells. Investigation of the antiproliferative effect of SAHA and VPA revealed that BMSCs and high concentration of interleukin-6 had partial protective effect against SAHA or both inhibitors, respectively. No effect of ECM components on the efficiency of HDACi was observed. We further revealed that VPA down-regulated STAT3 phosphorylation while both inhibitors decreased Akt phosphorylation. In conclusion, VPA and SAHA might represent an additional therapeutic strategy in the PCL treatment. Protective effect of BMM should be taken into account when investigating prospective therapeutic agents against plasma cell disorders.
\end{abstract}

Key words: bone marrow microenvironment, drug resistance, histone deacetylase inhibitors, multiple myeloma, plasma cell leukemia

Plasma cell leukemia (PCL) is a lymphoproliferative disorder characterized by high level of monoclonal plasma cells in the bone marrow and in the peripheral blood. It is considered to be a rare variant of multiple myeloma (MM) and is associated with poor prognosis with median survival counted in months $[1,2]$. PCL can arise de novo (primary $\mathrm{PCL}$ ) or as a leukemic transformation of existing MM (secondary PCL). Despite the progressive treatment approaches comprising novel drugs like proteasome inhibitors (PI) and/ or immunomodulatory drugs (IMIDs) as well as combination chemotherapy $[3,4,5]$ and stem cell transplantation, the disease still remains incurable $[6,7,8]$. Histone deacetylase inhibitors (HDACi) are promising therapeutic agents for cancer treatment including multiple myeloma [9]. Inhibition of histone deacetylation results in an open chromatin structure and subsequently in changes in the gene transcription. This leads to apoptosis, differentiation and/or growth arrest of tumour cells both in vitro and in vivo $[10,11]$.
Suberoylanilide hydroxamic acid (SAHA) is an HDACi approved by the U.S. Food and Drug Administration for the treatment of cutaneous T-cell lymphoma. SAHA induces apoptosis and growth arrest in other haematological malignancies including myeloma and its efficacy increases in combination with other antimyeloma drugs $[12,13]$. Valproic acid (VPA) is primarily used in the treatment of epilepsy and as a mood stabilising drug. It has recently been identified as a potential anticancer drug due to its activity as HDACi. VPA induces apoptosis, growth inhibition and cell differentiation in several types of tumours $[14,15,16]$. Synergistic effect of VPA and antimyeloma drugs was also reported [17].

Bone marrow microenvironment (BMM) plays a critical role in the pathogenesis of plasma cell neoplasms including MM and PCL [18]. Adhesion of malignant plasma cells to bone marrow stromal cells (BMSCs) contributes to the production of several growth factors and cytokines including interleukin-6 (IL-6) which is considered to be one of the growth and survival 
factors in MM $[19,20]$. Stimulation of cells by IL-6 triggers phosphorylation of the Signal transducer and activator of transcription 3 (STAT3). Apart from IL-6, other growth factors as well as cytokines activate various signalling pathways protecting myeloma cells from apoptosis such as phosphatidyl/ inositol-3-kinase/Akt (PI3K/Akt), Ras/mitogen-associated protein kinase (Ras/MAPK) and NF- kappa B pathways [21]. Not only BMM but also oncogenic mutations are responsible for activation of signalling pathways involved in the tumour cell survival. It was reported that BMSCs can protect myeloma cells from drug-induced cell death and are responsible for myeloma drug resistance $[22,23]$.

In this study, we investigated the effect of SAHA and VPA on plasma cell leukemia cell line UHKT-944. We further focused on possible protective effect of BMM, especially myeloma derived BMSCs, against the treatment with these inhibitors.

\section{Materials and methods}

Chemicals and antibodies. Valproic acid was purchased from Cayman Chemicals (Michigan, USA), SAHA was supplied by Alexis (San Diego, USA). SAHA was dissolved as $40 \mathrm{mM}$ stock solution in DMSO (Sigma-Aldrich Inc., Missouri, USA) and stored at $4{ }^{\circ} \mathrm{C}$. VPA was dissolved in the culture medium as $300 \mathrm{mM}$ stock solution which was prepared fresh in each experiment. The general caspase inhibitor Q-VD-OPh was purchased from R\&D Systems (Minneapolis, Canada) and dissolved in DMSO as a 10 $\mathrm{mM}$ stock solution and stored at $-20^{\circ} \mathrm{C}$. Non-conjugated primary antibodies against pJAK2 (Tyr 1007/Tyr 1008)-R (Rabbit pAb sc-16566-R) were purchased from SantaCruz Biotechnology (Santa Cruz, CA, USA). Phospho-Akt (Ser473) Antibody \#9271, Phospho-Stat3 (Tyr705) (3E2) Mouse mAb \#9138, Phospho-(Ser/Thr) Akt Substrate Antibody \#9611 and HRP conjugated secondary antibodies were purchased from Cell Signaling (Cell Signaling Technology, Inc., Danvers, MA, USA). Anti- $\beta$-Actin antibody, Mouse monoclonal (clone AC-15) A1978 was purchased from Sigma-Aldrich.

Cell line. IL-6-dependent plasma cell leukemia cell line UHKT-944 was established in our laboratory in 2010 [20]. Cells were cultivated in RPMI-1640 medium (Biochrom, Berlin, Germany) supplemented with $1 \mathrm{ng} / \mathrm{mL}$ recombinant human IL-6 (Invitrogen, Carlsbad, CA, USA), 10\% fetal bovine serum (Biochrom), $100 \mathrm{U} / \mathrm{mL}$ penicillin and $100 \mu \mathrm{g} /$ $\mathrm{mL}$ streptomycin (Sigma-Aldrich) in a humidified 5\% $\mathrm{CO}_{2}$ atmosphere at $37^{\circ} \mathrm{C}$.

Bone marrow stromal cells (BMSCs). Bone marrow samples were obtained from newly diagnosed patients with MM or patients with relapsed myeloma at the $1^{\text {st }}$ Department of Internal Medicine, Division of Hematology, General Faculty Hospital (Prague, Czech Republic). Mononuclear cells were separated by gradient centrifugation using Histopaque ${ }^{\infty}-1077$ (Sigma-Aldrich) and cultivated in a glass Erlenmeyer flask in RPMI-1640 medium without IL-6. BMSCs were developed after 1-2 weeks from the culture initiation. Non-adherent cells were removed and adherent cells with fibroblast-like morphology were cultured in IL-6 free medium until they reached $100 \%$ confluence. The medium was changed twice a week. For the experiments, BMSCs were detached by Trypsin-EDTA (Sigma-Aldrich), washed once in fresh medium and seeded at equal cell density in $50 \mathrm{~mL}$ glass Erlenmeyer flasks.

Cell cultivation in BMSCs surroundings. UHKT-944 cells $\left(2.5 \times 10^{5} \mathrm{cell} / \mathrm{s} / \mathrm{mL}\right)$ were seeded in $50 \mathrm{ml}$ glass Erlenmayer flasks with or without BMSCs. Cells were allowed to interact with BMSCs for 3 days and thereafter HDACi were added to reach final concentrations of $0.5 \mathrm{mM}$ or $1 \mathrm{mM}$ VPA and $1 \mu \mathrm{M}$ or $1.5 \mu \mathrm{M}$ SAHA.

Cell cultivation in ECM surroundings. A tissue culture 96-well plate was coated with MaxGel ECM (Sigma-Aldrich) which contains human extracellular matrix components. To create a three-dimensional environment we followed the procedure according to the manufacturer. Briefly, MaxGel was diluted 1:4 with medium and $75 \mu \mathrm{l}$ of diluted MaxGel was added into the plate. The plate was incubated for 4 hours at $37^{\circ} \mathrm{C}$ in humidified $5 \% \mathrm{CO}_{2}$ incubator. The remaining solution was removed and the plate was allowed to air- dry for 30 minutes. UHKT-944 cells were plated at $2 \times 10^{4}$ cells/well. After 48 hours of incubation with ECM, HDACi were added to reach final concentrations of $0.5 \mathrm{mM}$ or $1 \mathrm{mM}$ VPA and 1 $\mu \mathrm{M}$ or $1.5 \mu \mathrm{M}$ SAHA.

Cell cultivation in the presence of various concentrations of interleukin-6 (IL-6). UHKT-944 cells $\left(2.5 \times 10^{5}\right.$ cells $\left./ \mathrm{mL}\right)$ were seeded in $50 \mathrm{~mL}$ glass Erlenmeyer flasks with different IL- 6 concentrations: $0.2 \mathrm{ng} / \mathrm{mL}, 1 \mathrm{ng} / \mathrm{mL}$ and $3.3 \mathrm{ng} / \mathrm{mL}$. Cells were incubated for 3 days and thereafter HDACi were added to reach final concentrations of $0.5 \mathrm{mM}$ or $1 \mathrm{mM}$ VPA and 1 $\mu \mathrm{M}$ or $1.5 \mu \mathrm{M}$ SAHA.

Cell proliferation assay. Cell proliferation was measured after 24 and 48 hours of treatment using AlamarBlue ${ }^{\circ}$ assay (Invitrogen) following manufacturer's instructions. Briefly, $100 \mu \mathrm{L}$ of cell suspension from each Erlenmeyer flask was transferred to 96-well plate and $10 \mu \mathrm{L}$ of AlamarBlue reagent was added to each well. In case of cell proliferation in ECM surrounding, $10 \mu \mathrm{L}$ of alamarBlue reagent was added directly to each well. The plate was incubated for one hour at $37^{\circ} \mathrm{C}$. The fluorescence intensity was measured on BMG FluoStar Galaxy microplate reader (MTX Lab Systems, Inc., VA, USA).

Caspase-3 activity measurement. Caspase-3/CPP32 colorimetric assay kit (BioVision, CA, USA) was used to detect apoptosis in UHKT-944 cells after treatment with various concentrations of SAHA and VPA, in the presence/absence of $10 \mu \mathrm{M}$ pan-caspase inhibitor Q-VD-OPh. For the measurement, the cells $\left(5 \times 10^{5}\right.$ cells $)$ were cultured in 6 - well plates and incubated for 24 hours with various concentrations of VPA and SAHA. Cells were harvested and lysed. The protein concentration in cell lysates was determined using Bio-Rad protein assay (Bio-Rad Laboratories, CA, USA) and $100 \mu \mathrm{g}$ of protein was used in each experiment. The assay was performed 
according to manufacturer's instructions. Absorbance was measured at $405 \mathrm{~nm}$ on Dynatech Microplate Reader Model MRX (Dynatech Laboratories, Chantilly, VA, USA).

Annexin-V apoptotic assay. Annexin-V-FLUOS staining kit (Roche Diagnostics GmbH, Mannheim, Germany) was used to detect apoptosis or necrosis in UHKT-944 cells. For the measurement, the cells $\left(4 \times 10^{5}\right.$ cells/ mL) were cultured in 6-well plates and incubated for 24 hours with various concentrations of VPA and SAHA in the presence/absence of $10 \mu \mathrm{M}$ pan-caspase inhibitor Q-VD-OPh. The assay was performed according to manufacturer's instructions. Samples were analysed by flow cytometry on Coulter Epics XL (Beckman Coulter Inc., Miami, USA). Data were evaluated using WinMDI 2.8 software (BD, Franklin Lakes, NJ, USA).

Measurement of adhesion to ECM. To test the adhesion of UHKT-944 cells to MaxGel ECM, the cells were seeded into tissue culture 96-well plate coated with MaxGel ECM. Human erythroleukemic cell line (HEL) was used as a positive control. The measurement was performed according to a previously described procedure [25].

Cytokine measurement. IL- 6 produced by BMSCs in the presence of UHKT- 944 cells was measured at the Department of Clinical Biochemistry (Thomayer Hospital, Prague, Czech Republic) on Cobas 6000 analyser (Roche Diagnostics, Prague, Czech Republic). Briefly, $6 \mathrm{~mL}$ of fresh media with $1.5 \times 10^{6}$ cells was added to Erlenmeyer flask with or without BMSCs layer. After 3 days, $2 \mathrm{~mL}$ media was centrifuged and supernatant stored at $-20^{\circ} \mathrm{C}$ until analysis.

Cell cycle analysis. Cell cycle analysis was investigated after 48 hours incubation of UHKT-944 cells with indicated concentrations of SAHA and VPA (cultured alone or with BMSCs). The cells $\left(5 \times 10^{5}\right)$ were harvested, washed once in PBS, fixed in $4.5 \mathrm{~mL}$ of cold $70 \%$ ethanol, incubated for 30 minutes in $4{ }^{\circ} \mathrm{C}$ and stored at $-20^{\circ} \mathrm{C}$ until analysis. On the day of the analysis, the cells were washed twice in PBS and incubated for $2 \mathrm{~h}$ at $4^{\circ} \mathrm{C}$ in $0.5 \mathrm{~mL}$ of the modified Vindelov's propidium iodide buffer (10 mM Tris, pH 8.0, $1 \mathrm{mM} \mathrm{NaCl}, 0.1 \%$ Triton X-100, $20 \mu \mathrm{g} /$ $\mathrm{mL}$ propidium iodide and $10 \mathrm{~K}$ units ribonuclease $\mathrm{A}$ ). DNA content was determined using LSR Fortessa flow cytometer (BD Biosciences).

ELISA (Enzyme-linked immunosorbent assay). For the determination of pSTAT3 level, UHKT- 944 cells $\left(2.5 \times 10^{5}\right.$ cells/ $\mathrm{mL}$ ) were seeded in $50 \mathrm{ml}$ glass Erlenmeyer flasks with or without BMSCs. After 48 hours, leukemic cells were harvested and lysed; the cell lysate was diluted to reach $0.1 \mathrm{mg} / \mathrm{mL}$ protein. Phosphorylated STAT3 level was measured after 48 hours treatment with SAHA and VPA using PathScan ${ }^{\circ}$ PhosphoStat3 (Tyr705) Sandwich ELISA kit (Cell Signaling) following manufacturer's instructions. Absorbance was measured at 450 $\mathrm{nm} / 650 \mathrm{~nm}$ as reference wavelength on Dynatech Microplate Reader Model MRX (Dynatech).

Western blot analysis. For western blot analysis, the cells were incubated with indicated concentrations of SAHA and VPA for 48 hours (cultured alone or with BMSCs). The cells were washed twice in PBS, lysed in NP40 cell lysis buffer
(Invitrogen) supplemented with PMSF (Roche) and protease and phosphatase inhibitors (Sigma-Aldrich). Proteins were separated by $12 \%$ SDS-PAGE and transferred onto PVDF membrane (GE Healthcare Life Sciences, Piscataway, NJ, USA). The membrane was blocked with 3\% BSA (Roche), washed and incubated with appropriate primary antibodies at $4^{\circ} \mathrm{C}$ overnight. Then the membrane was washed, incubated with HRP-conjugated secondary antibodies for $2 \mathrm{~h}$ at the room temperature. Bound antibodies were detected with enhanced chemiluminiscence SuperSignal West Dura Extended Duration Substrate (Thermo Fisher Scientific, Inc., Rockford, IL, USA). Anti $\beta$-Actin (Sigma-Aldrich) was used as a loading control. The chemiluminiscence signal from the membranes was detected and evaluated using G-box iChemi XT4 digital imaging device (Syngene Europe, Cambridge).

Data evaluation. Data were evaluated using MedCalc statistical software version 13 (MedCalc ${ }^{\oplus}$, Mariakerke, Belgium) using Student's t-test and Wilcoxon paired samples test or using GraphPad software version 5.02.

\section{Results}

SAHA and VPA induce apoptosis in UHKT-944 cells. To detect an early stage of apoptosis or late apoptosis/necrosis, the cells were stained with Annexin V and PI and analysed by flow cytometry (representative flow dotplots are presented in Supplementary Figure 1). Both SAHA and VPA increased phosphatidylserine externalization and the number of necrotic cells. When the cells were co-treated with the pan-caspase inhibitor Q-VD-OPh, the effects were largely reduced suggesting that the cell death caused by these inhibitors is caspasedependent (Figure 1A). As shown in Figure 1B and C, both VPA and SAHA induced apoptosis via caspase-3 activation in UHKT-944 cells.

Bone marrow microenvironment (BMM) influences the effect of SAHA and VPA. To assess whether BMM can contribute to cell survival in the presence of the used drugs, we simulated this microenvironment using commercially available components of ECM and also using BMSCs derived from patients diagnosed with MM. Antiproliferative effect of SAHA and VPA was analysed using AlamarBlue assay. Both inhibitors at the used concentrations inhibited cell proliferation after 24 and 48 hours (Figure 2). We did not find any difference in the inhibition of cell proliferation between cells cultured alone or in the presence of ECM components (Supplementary Figure 2). BMM simulated by ECM proteins had thus no protective effect. The reason for that could be the fact that only $10.5 \pm 0.9 \%$ cells adhered to plate coated with MaxGel (data not shown). As HEL cell line, which was used as a positive control, had about $70 \%$ of adherent cells, the interaction of UHKT-944 cells with ECM proteins is relatively weak. On the other hand, differences in the cell proliferation were observed between the cells co-cultured with BMSCs and cultured alone, especially in the presence of SAHA suggesting that BMSCs have partial protective effect against SAHA treatment (Figure 


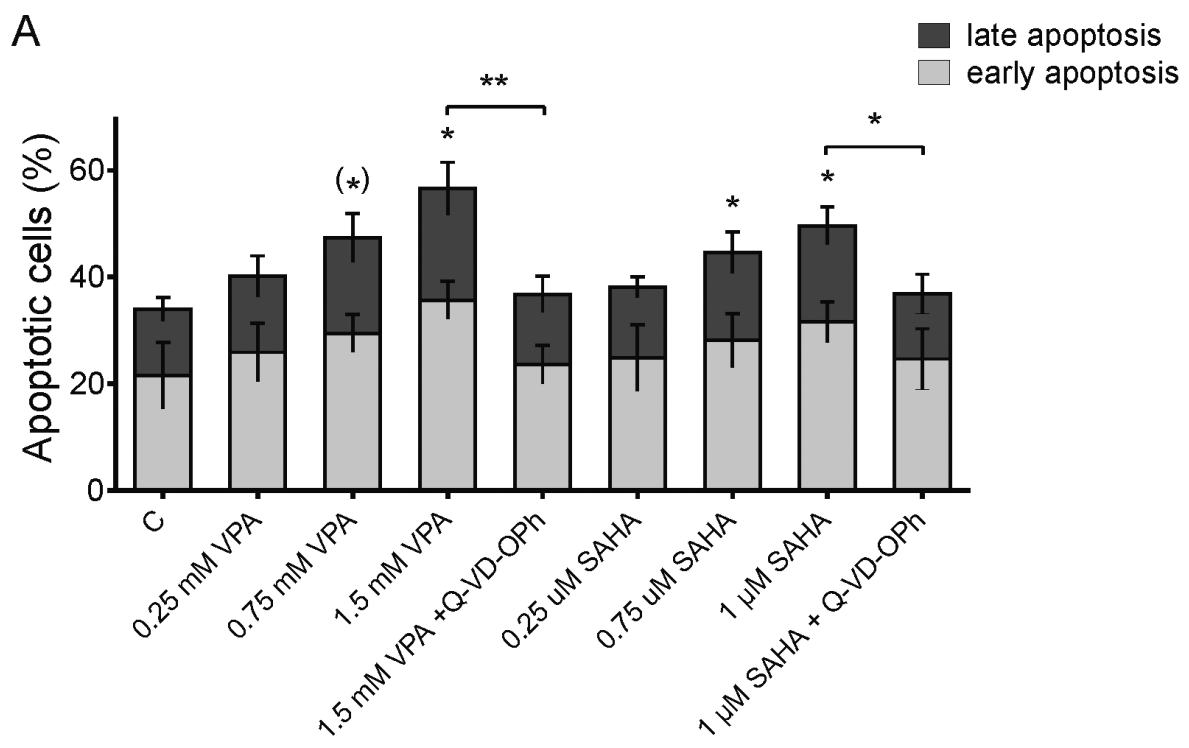

B

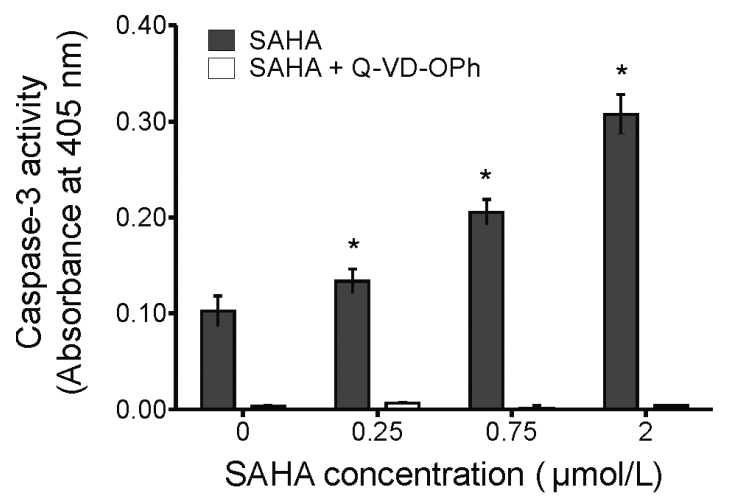

C

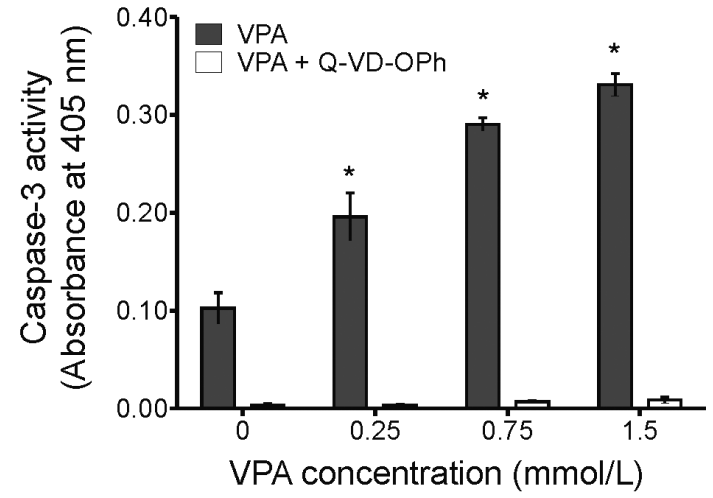

Figure 1. Apoptosis induction by SAHA and VPA.

Summary graph showing the effect of SAHA and VPA on apoptosis in UHKT-944 cells (A) (illustrative dotplots are presented in Supplementary Figure 1). Apoptosis was measured using flow cytometry with Annexin V-Alexa 488 and propidium iodide (PI) staining. Cells were treated for 24 hours with indicated concentrations of SAHA and VPA in the presence/absence of $10 \mu \mathrm{M}$ pan-caspase inhibitor Q-VD-OPh. The effect of SAHA (B) and VPA (C) on caspase-3 activity was measured with Caspase-3/CPP32 colorimetric assay kit. The results represent mean \pm standard deviation of four independent experiments. The data were evaluated using paired Student's t-test, ${ }^{\star} \mathbf{P}<0.05,{ }^{*} \mathbf{P}<0.001,\left({ }^{*}\right) \mathbf{P}<0.05$ in late apoptotic cell fraction only.

2A). Similarly BMSCs influence the rate of apoptosis, both in the untreated controls and after SAHA and VPA treatment. Although BMSCs do not protect cells from the toxic effect of the inhibitors and apoptotic cell fraction increases significantly at higher inhibitor concentrations, there is higher portion of intact UHKT-944 cells when they are co-cultured with BMSCs (Figure 2B).

Because we proved that BMSCs produce IL-6 (data not shown), we further wanted to address the question whether IL-6 alone could be responsible for these observations. Although the UHKT-944 cells were cultivated in RPMI-1640 medium supplemented with $1 \mathrm{ng} / \mathrm{mL}$ IL-6, the real concentration of IL- 6 measured by means of immunoassay (see methods) was $0.2 \mathrm{ng} / \mathrm{mL}$. Concentration of IL- 6 which cor- responded to the mean concentration produced by BMSCs in the experiments - i.e. $1 \mathrm{ng} / \mathrm{mL}$ ( 5 times higher than in the culture medium from the control cells) did not have any effect, however higher concentration of IL-6 (3.3 ng/mL) had a tendency to decrease the antiproliferative effect of both VPA and SAHA (Figure 2C, 2D). The concentration of IL-6 was measured repeatedly in freshly prepared medium.

SAHA and VPA had no effect on cell cycle distribution. Cell cycle analysis revealed that VPA and SAHA had no significant effect on the cell cycle distribution of UHKT-944 cells (Figure 3A, 3B). We further observed no differences in the cell cycle distribution between the cells cultured alone or with BMSCs. Using the cell cycle analysis, we also quantified the percentage of the cells in sub-G1 phase which 
A

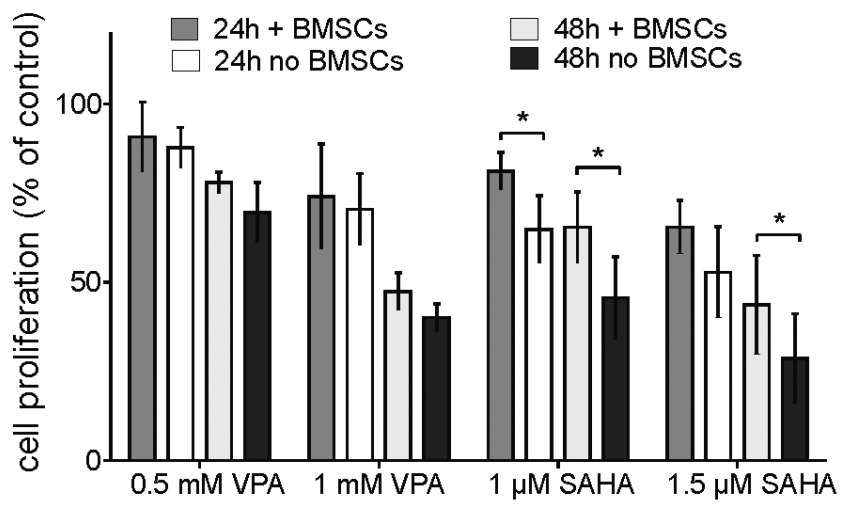

C

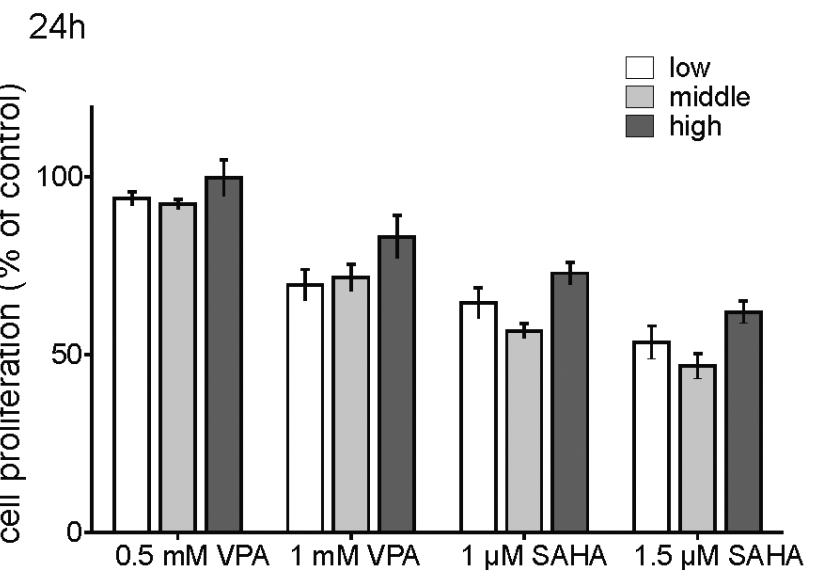

B

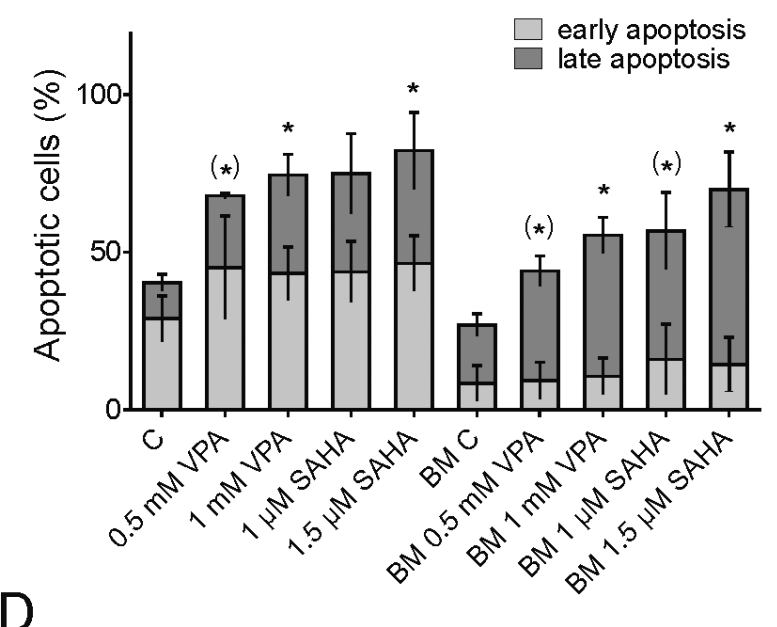

$48 \mathrm{~h}$

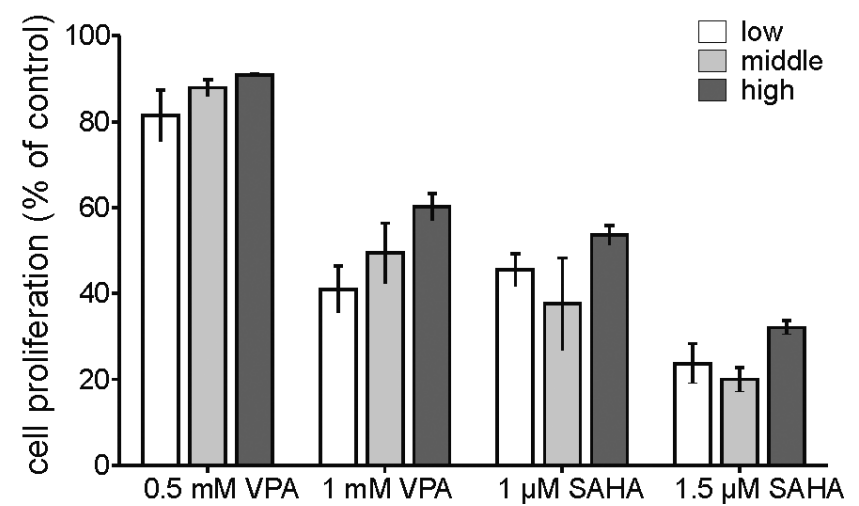

Figure 2. Impact of BMSCs microenvironment to SAHA and VPA effects.

UHKT-944 cells were cultivated alone, with BMSCs (A, B), or various IL-6 concentrations $(\mathrm{low}-0.2 \mathrm{ng} / \mathrm{mL}, \mathrm{middle}-1 \mathrm{ng} / \mathrm{mL}$, high - $3.3 \mathrm{ng} / \mathrm{mL})(\mathrm{C}$, D). Cells were treated with indicated concentrations of SAHA and VPA for $24(\mathrm{~A}, \mathrm{C})$ and 48 hours (A, B, D). Cell proliferation was measured using AlamarBlue assay (A, C, D). Apoptosis was measured using flow cytometry with Annexin V and propidium iodide (PI) staining (B). The results represent mean \pm standard deviation of six $(A)$, four $(B)$ or three $(C$ and $D)$ independent experiments. $\left.{ }^{*}\right) P<0.05$ in late apoptotic cell fraction only.

represents a population of late apoptotic cells (Figure 3C). We found that both VPA and SAHA significantly increased sub-G1 cell population $(\mathrm{P}<0.05)$, representative flow data are presented in Supplementary Figure 3. When the cells were 48 hours treated with SAHA in the presence of BMSCs, the number of apoptotic cells was lower in comparison with cells cultured with SAHA alone: $28.3 \pm 10.1 \%$ of cells in sub-G1 versus $39.4 \pm 7.9 \%(1 \mu \mathrm{M}$ SAHA $)$ and $32.1 \pm 14.9$ versus $50.3 \pm 7.1 \%(1.5 \mu \mathrm{M}$ SAHA). However, these results were not found statistically significant according to Wilcoxon paired sample test.

VPA and SAHA influence JAK/STAT and PI3K/Akt pathways. To find out whether SAHA and VPA target JAK/ STAT or PI3K/Akt signalling pathways, we investigated the phosphorylation status of JAK2, STAT3, Akt and also the profile of Akt phospho- serine/threonine substrates. Results from ELISA test of pSTAT3 (Tyr 705) (Figure 4) showed that VPA down-regulated the phosphorylation of STAT3 especially when the leukemia cells were co-cultured with BMSCs. This was confirmed by western blot analyses where we simultaneously tested the phosphorylation status of STAT3, JAK2 and Akt (Figure 5A-D) Western blot analyses showed the decrease of phosphorylation of STAT3 (Figure 5B) and pJAK2 (Figure 5C). Both VPA and SAHA also down-regulated the phosphorylation at the tested Akt phosphorylation sites (Figure 5D). No significant/minimal differences were found between the cells cultured alone or co-cultured with BMSCs when VPA was present. Interestingly, co-culture of UHKT-944 cells with 

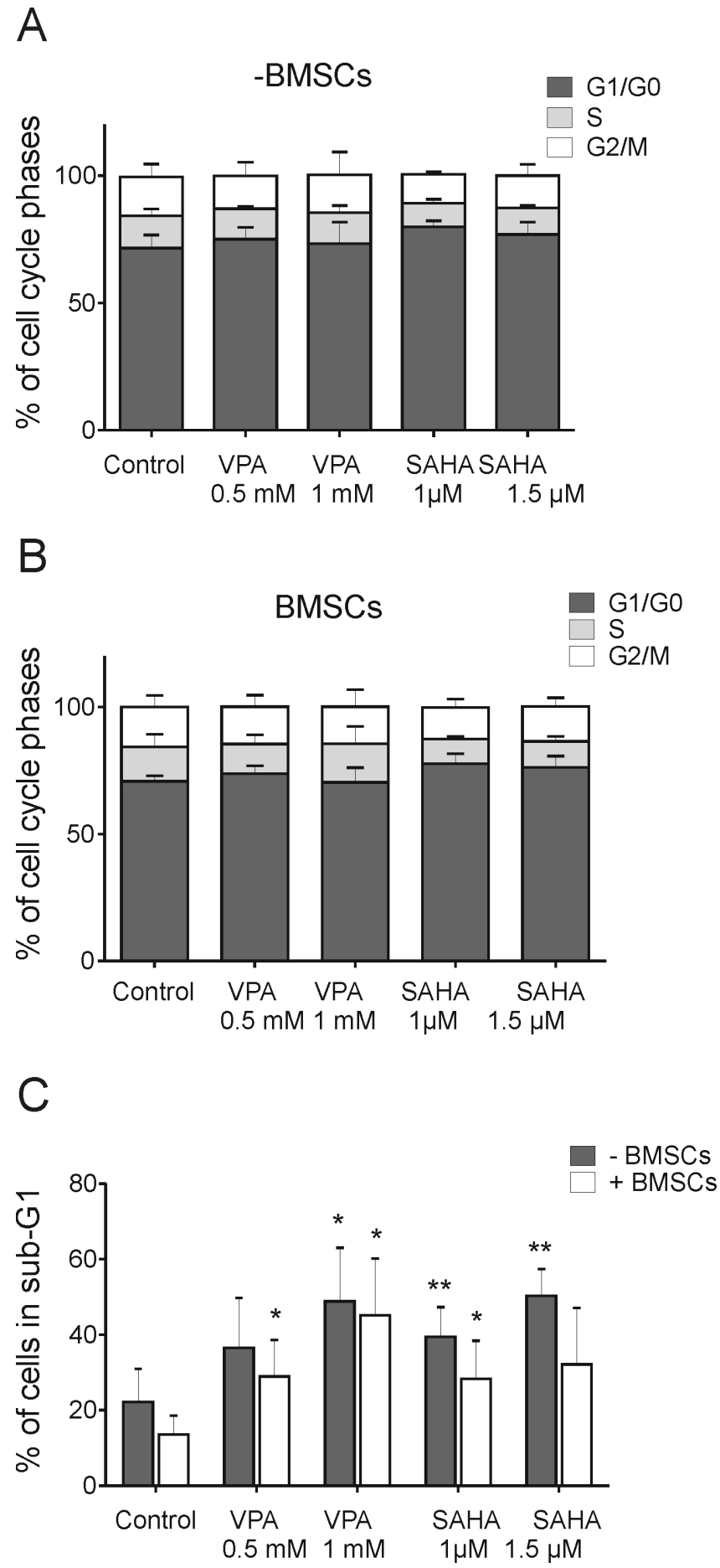

Figure 3. Cell cycle analysis of UHKT-944 cells +- BMSCs.

UHKT-944 cells were cultured alone (A) or with BMSCs (B) after treatment with indicated concentrations of SAHA and VPA for 48 hours. Cell cycle distribution was analysed by flow cytometry using propidium iodide (representative flow data are presented in Supplementary Figure 3). Cells show no significant differences in the relative amounts in G1/G0, $\mathrm{S}$ and G2/M cell cycle phases after SAHA and VPA treatment (A, B). The cells in sub-G1 phase representing late apoptosis/necrosis were evaluated separately $(C)$. Data represent mean \pm standard deviation of four independent experiments. The data were evaluated using paired Student's t-test, ${ }^{\star} \mathbf{P}<0.05$, ${ }^{\star *} \mathbf{P}<0.001$.

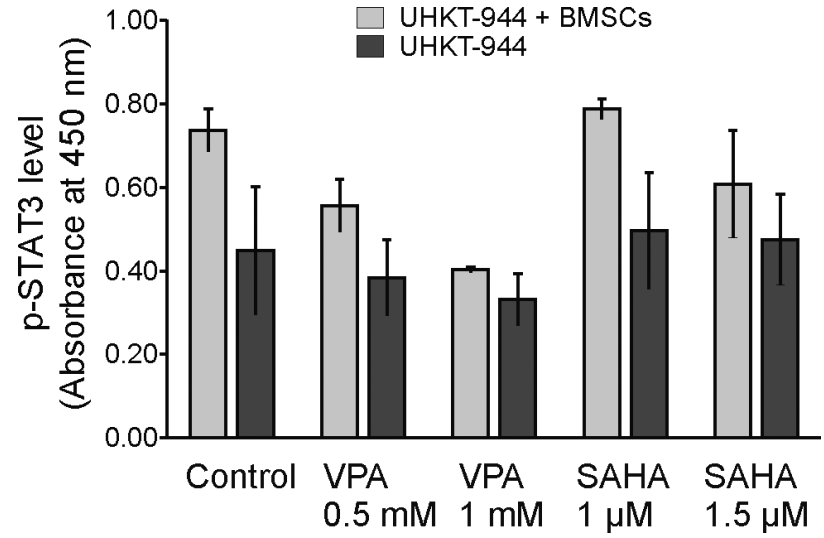

Figure 4. Effect of VPA and SAHA on STAT3 phosphorylation. pSTAT3 (Tyr705) level was measured by means of ELISA in UHKT-944 cells. Cells were co-cultured with or without BMSCs and incubated with indicated concentrations of SAHA and VPA for 48 hours. Data represent mean \pm standard deviation of three independent experiments. Differences were not statistically significant, $\mathrm{P}>0.05$.

BMSCs slightly influenced the phosphorylation changes in case of SAHA treatment. The effect is more evident in Akt substrates phosphorylation changes (Figure 5E, 5F).

\section{Discussion}

Bone marrow microenvironment promotes growth and survival of tumour cells and could be also responsible for resistance to treatment $[18,22,26,27]$. Therefore, the search for new therapeutic agents which could overcome the resistance is needed. HDACi have been shown to induce apoptosis, differentiation and inhibition of cell growth of a wide variety of transformed cells $[28,29]$. Several HDACi have also been shown as potential antimyeloma agents $[30,31]$. In this study, we showed that VPA and SAHA are able to activate caspase-3, induce apoptosis and inhibit the growth of plasma cell leukemia cell line UHKT-944. Using a broad spectrum pan-caspase inhibitor Q-VD-OPh, we found that inhibition of caspases decreased the number of early apoptotic as well as late apoptotic/necrotic cells after VPA and SAHA treatment. Contrary to our results, another study revealed that treatment of MM.1S cell line with SAHA did not induce cleavage of caspase- 3 and the pan-caspase inhibitor ZVAD-FMK did not protect the cells against SAHA suggesting that caspases have a minor role in mediating SAHA-induced apoptosis in MM cells [13]. Both VPA and SAHA have been shown to induce both caspase-dependent and -independent apoptosis or even non-apoptotic cell death and inhibits the proliferation in other myeloma cell lines as well as in primary multiple myeloma cells $[13,32,33,34]$.

MM as well as PCL represent one of the most studied hematological malignancies in connection with BMM, however a lot of studies investigating the effect of new therapeutics do not consider potential effect of this microenvironment. Therefore, 

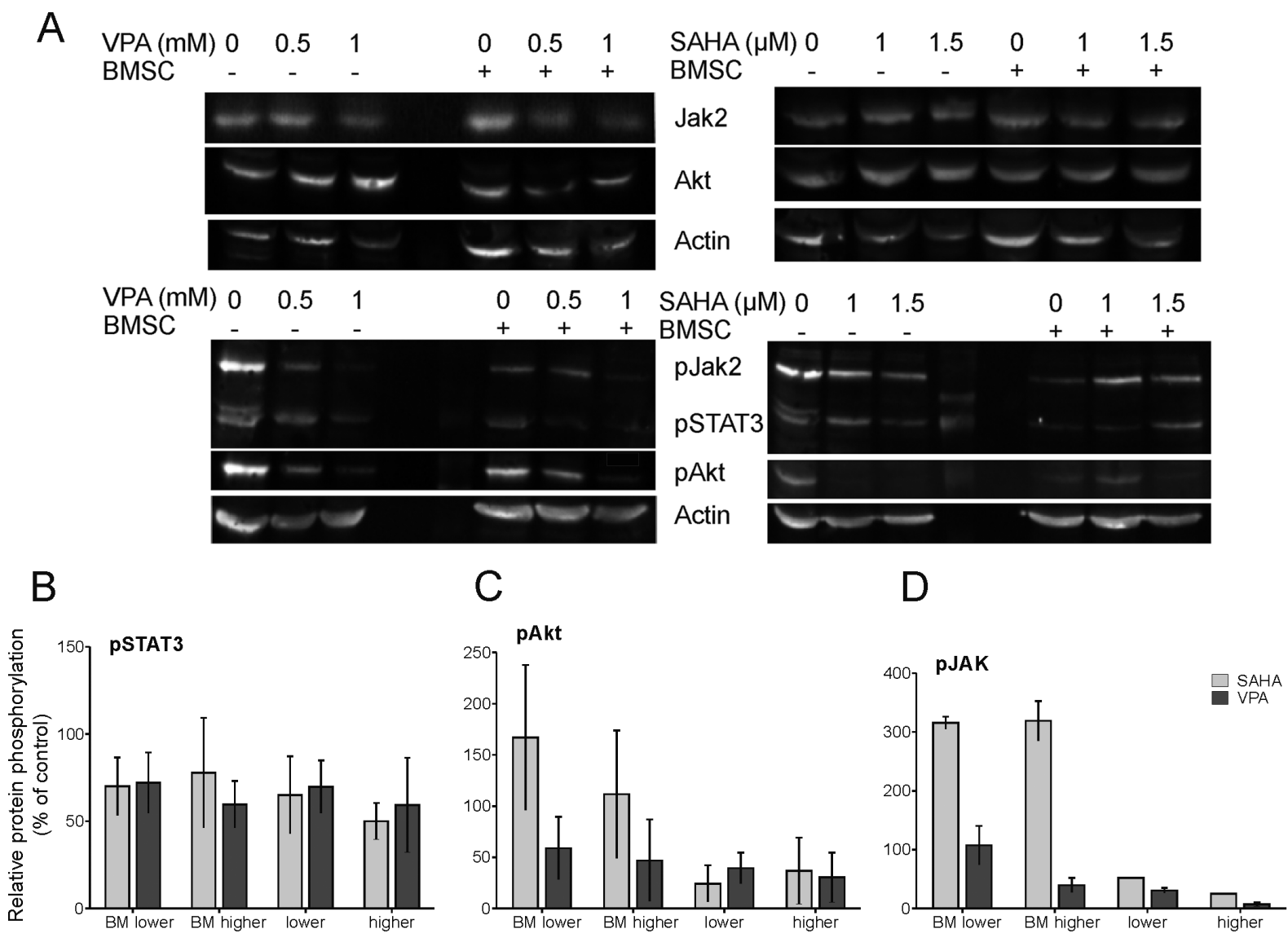

E pSer/Thr Akt substrates

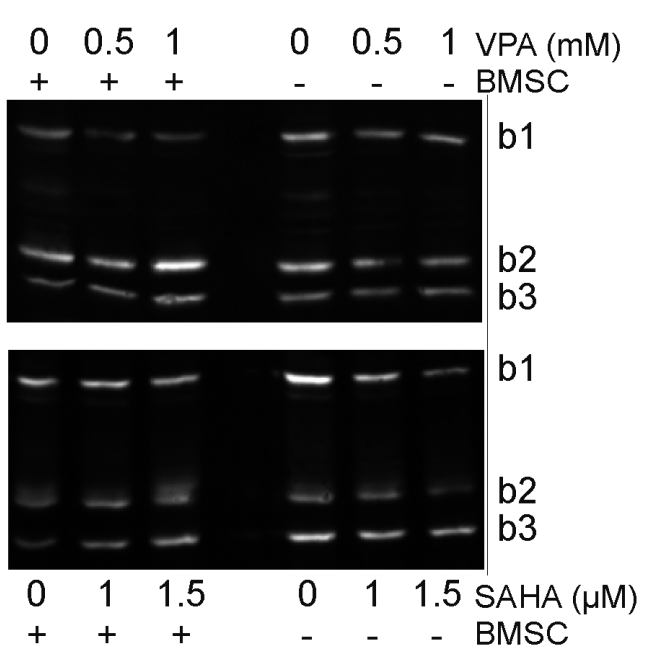

$\mathrm{F}$

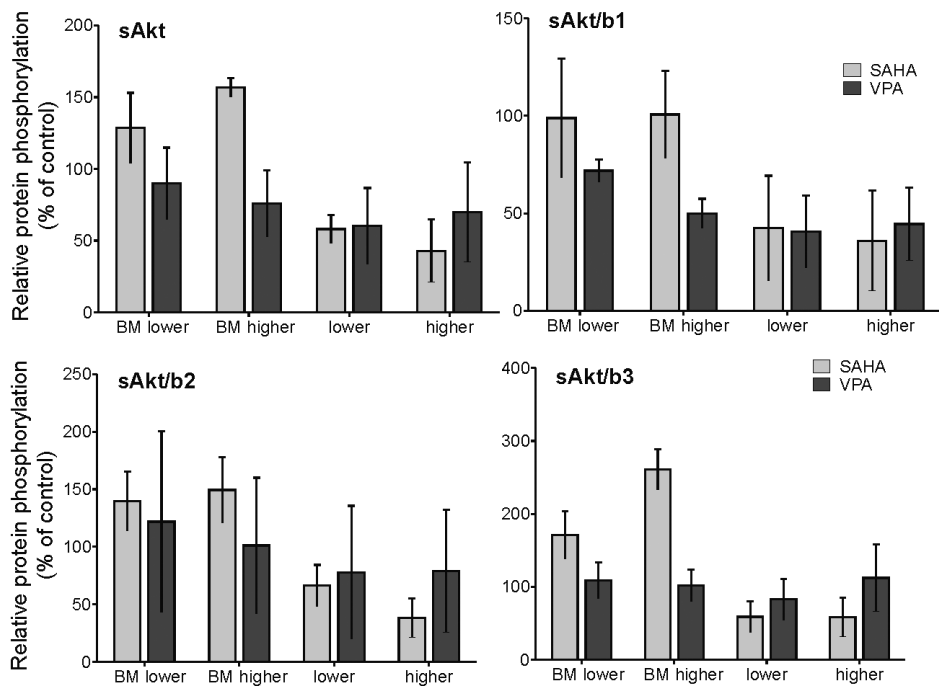

Figure 5. Effect of SAHA and VPA on the activity of JAK/STAT and PI3K pathways. Illustrative western blots (A) and graphs showing phosphorylation status of STA3 (B), Akt (C) and JAK2 (D) proteins in cells cultivated with/without BMSCs are presented in graphs summarizing four independent experiments. Representative western blot showing changes in phosphorylation Phospho (Ser/Thr) Akt substrates profiles (E) is presented together with graphs of the whole phosphorylation signal (sAkt) and intensities of bands b1, b2 and b3 (F). The results represent mean \pm standard deviation of three independent experiments. Activity of JAK/STAT pathway has been tested via phosphorylation of JAK2 (pTyr 1008) and STAT3 (pTyr705), PI3K/Akt pathway via pAkt (pSer473) and Ser/Thr phosphorylated Akt substrates. Relative protein phosphorylation was normalized to $\beta$-actin used as a loading control. Phosphorylation in graphs is presented/expressed as a\% of untreated control (+- BMSC). BM lower - treatment with $0.5 \mathrm{mM}$ of VPA or $1 \mu \mathrm{M}$ SAHA together with BMSC, BM higher$1 \mathrm{mM}$ of VPA or $1.5 \mu \mathrm{M}$ SAHA together with BMSCs; lower- treatment with $0.5 \mathrm{mM}$ of VPA or $1 \mu \mathrm{M}$ SAHA, higher- $1 \mathrm{mM}$ of VPA or $1.5 \mu \mathrm{M}$ SAHA. 
we studied the effect of HDACi in the presence of BMM and found that BMSCs derived from MM patients partly decreased the antiproliferative effect of SAHA in contrast to VPA. Previous studies showed that BMSCs protect myeloma cells from apoptosis induced by bortezomib which is considered to be one of the most promising agents against MM [23]. Not only live stromal cells, but also the interaction between MM cells and extracellular matrix components including fibronectin influence the myeloma cell survival [35]. Interestingly, our data revealed that extracellular matrix components had no protective effect against any of HDACi used. One of the reasons could be the fact that only less than $11 \%$ of UHKT-944 cells were able to adhere to commercial MaxGel ECM which contains human ECM components. UHKT-944 cells might adhere to another ECM protein which is absent from MaxGel or to a component which is not present in sufficient quantities.

We found that MM-derived BMSCs produce IL-6 (data not shown) which can be other factor responsible for myeloma cell survival [32]. Our data revealed that only high concentration of IL-6 was able to partly decrease the antiproliferative effect of VPA and SAHA suggesting that the protective effect of BMM may be partly due to IL-6 alone but also to the presence of stromal cells or other factors they produce. These observations are consistent with previous studies where IL- 6 as well as insulin-like growth factors were found to inhibit the druginduced cell death in MM [36, 37].

In several studies, HDACi have been shown to induce a cell cycle arrest in G1/G0 phase in MM cell lines $[32,33,38]$ which is in contrast to our data. Neither SAHA nor VPA had any significant effect on the cell cycle distribution of UHKT-944 cells cultured alone or in the presence of BMSCs. Hence, these compounds can influence the cell growth without causing cell cycle arrest. In agreement with our data, Du et al reported that another HDACi, sodium butyrate, did not arrest the cell cycle in the G1 phase; however, this occurred when sodium butyrate was combined with the demethylating agent 5-Aza-2'deoxycytidine [39]. Similarly, panobinostat, one of promising HDACi for combined therapy $[40,41]$ showed no effect on MM cell cycle distribution while used alone or in combination with the proteasome inhibitor carfilzomib [42]. Reasons for discrepancies in studies are unclear, but different type of treatment involving different cell lines may be responsible for these different results.

In our study, we further focused on JAK/STAT and PI3K/ Akt signalling pathways whose dysregulation is associated with myeloma cell survival. Our data showed that VPA inhibited STAT3 phosphorylation even when the cells were co-cultured with BMSCs where we had assumed only partial effect. The reason for this assumption was the fact that BMSCs produce high concentration of IL- 6 which is one of the factors responsible for JAK/STAT pathway activation. Our results suggest that inhibition of JAK/STAT pathway represents one of the mechanisms of action of VPA in PCL or MM. In consistency with our data, VPA has been shown to inhibit STAT3 phosphorylation in natural killer cells as reported by Zhu et al. [43]. Apart from VPA, a novel JAK inhibitor AZD1480 was shown to block JAK/STAT3 signalling in myeloma cells cultured alone, or even when co-cultured with BMSCs, similarly as in our experimental system [44]. Western blot analyses revealed that both SAHA and VPA were able to affect the phosphorylation of Akt and Akt substrates, thus both inhibitors influence more pathways important to cell survival. Other drugs have been shown to inhibit Akt phosphorylation leading to myeloma cell death [45]. When the cells were co-cultured with BMSCs in the presence of SAHA, we found some differences in the phosphorylation status of proteins involved in important survival pathways in MM. We suppose this might be attributed to the presence of BMSCs and points to the need of testing the potential antimyeloma drugs in the presence of BMM as evidenced by several studies $[46,18]$.

Concerning molecular mechanisms of the antitumor activity of SAHA, Mitsiades et al. showed that SAHA downregulated the expression of receptor genes involved in proliferation and survival, such as the insulin-like growth factor receptor and IL-6 receptor, antiapoptotic molecules, DNA synthesis/repair enzymes etc [47]. However, when we focus on IL-6, HDACi can induce apoptosis of MM cell lines independently of decreased IL-6 receptor expression as reported by Lavelle et al. [48].

In conclusion, based on our results/observations and on published results by others, it is evident that VPA and SAHA could be used in the treatment of MM and PCL. The influence of these inhibitors depends on the cell type and also on the microenvironment which should be taken into account when novel therapeutic drugs against plasma cell disorders are investigated.

Supplementary information is available in the online version of the paper.

Acknowledgements: The work was supported by the Ministry of Health of the Czech Republic (Project for conceptual development of research organization No 00023736) and by European Union (grants ERDF OPPK CZ.2.16/3.1.00/24001 and CZ.2.16/3.1.00/28007).

\section{References}

[1] JIMENEZ-ZEPEDA VH, DOMINGUEZ VJ. Plasma cell leukemia: a rare condition. Ann Hematol 2006; 85: 263-267. https://doi.org/10.1007/s00277-005-0054-4

[2] TIEDEMANN RE, GONZALEZ-PAZ N, KYLE RA, SANTANA-DAVILA R, PRICE-TROSKA T et al. Genetic aberrations and survival in plasma cell leukemia. Leukemia 2008; 22: 1044-1052. https://doi.org/10.1038/leu.2008.4

[3] OGAWA Y, OGURA M, TOBINAI K, ANDO K, SUZUKI T et al. A phase I study of vorinostat combined with bortezomib in japanese patients with relapsed or refractory multiple myeloma. Int J Hematol 2016; 103: 25-33. https://doi.org/10.1007/ $\underline{\text { s12185-015-1897-7 }}$ 
[4] TOTANI H, RI M, KATO C, NAKASHIMA T, SUZUKI N et al. Phase I study of once weekly treatment with bortezomib in combination with lenalidomide and dexamethasone for relapsed or refractory multiple myeloma. Int J Hematol 2016; 103: 316-321. https://doi.org/10.1007/s12185-015-1925-7

[5] KIKUCHI J, KOYAMA D, MUKAI HY, FURUKAWA Y. Suitable drug combination with bortezomib for multiple myeloma under stroma-free conditions and in contact with fibronectin or bone marrow stromal cells. Int J Hematol 2014; 99: 726-736. https://doi.org/10.1007/s12185-014-1573-3

[6] ESPARIS-OGANDO A, ALEGRE A, AGUADO B, MATEO G, GUTIERREZ $N$ et al. Bortezomib is an efficient agent in plasma cell leukemias. Int J Cancer 2005; 114: 665-667. https:// doi.org/10.1002/ijc.20793

[7] JOHNSTON RE, ABDALLA SH. Thalidomide in low doses is effective for the treatment of resistant or relapsed multiple myeloma and for plasma cell leukemia. Leuk Lymphoma 2002; 43: 351-354. https://doi.org/10.1080/10428190290006143

[8] KIM SJ, KIM J, CHO Y, SEO BK, KIM BS. Combination chemotherapy with bortezomib, cyclophosphamide and dexamethasone may be effective for plasma cell leukemia. Jpn J Clin Oncol 2007; 37: 382-384. https://doi.org/10.1093/jico/ $\underline{\text { hym } 037}$

[9] HIDESHIMA T, ANDERSON KC. Histone deacetylase inhibitors in the treatment for multiple myeloma. Int J Hematol 2013; 97: 324-332. https://doi.org/10.1007/s12185013-1290-3

[10] KIM HJ, BAE SC. Histone deacetylase inhibitors: molecular mechanisms of action and clinical trials as anti-cancer drugs. Am J Transl Res 2011; 3: 166-179.

[11] LANE AA, CHABNER BA. Histone deacetylase inhibitors in cancer therapy. J Clin Oncol 2009; 27: 5459-5468. https://doi. org/10.1200/JCO.2009.22.1291

[12] CHERIYATH V, GLASER KB, HEALAN-GREENBERG C, WARING JF, KALAYCIO $M$ et al. Epigenetic regulation of IFN- $2 \mathrm{~b}$ in multiple myeloma by a hydroxamic acid histone deacetylase (HDAC) inhibitor (SAHA) and a non-hydroxamic acid HDAC inhibitor (A-423378). J Clin Oncol 2007; 25: No 18S: 14048.

[13] MITSIADES N, MITSIADES CS, RICHARDSON PG, MCMULLAN C, POULAKI V et al. Molecular sequelae of histone deacetylase inhibition in human malignant B cells. Blood 2003; 101: 4055-4062. https://doi.org/10.1182/blood-200211-3514

[14] TANG R, FAUSSAT AM, MAJDAK P, PERROT JY, CHAOUI $\mathrm{D}$ et al. Valproic acid inhibits proliferation and induces apoptosis in acute myeloid leukemia cells expressing P-gp and MRP1. Leukemia 2004; 18: 1246-1251. https://doi. org/10.1038/sj.leu.2403390

[15] LI XN, SHU Q, SU JM, PERLAKY L, BLANEY SM et al. Valproic acid induces growth arrest, apoptosis, and senescence in medulloblastomas by increasing histone hyperacetylation and regulating expression of p21Cip1, CDK4, and CMYC. Mol Cancer Ther 2005; 4: 1912-1922. https://doi. org/10.1158/1535-7163.MCT-05-0184

[16] NERI P, TAGLIAFERRI P, DI MARTINO MT, CALIMERI $\mathrm{T}$, AMODIO $\mathrm{N}$ et al. In vivo anti-myeloma activity and modulation of gene expression profile induced by valproic acid, a histone deacetylase inhibitor. Br J Haematol 2008; 143: 520-531.

[17] WANG AH, WEI L, CHEN L, ZHAO SQ, WU WL et al. Synergistic effect of bortezomib and valproic acid treatment on the proliferation and apoptosis of acute myeloid leukemia and myelodysplastic syndrome cells. Ann Hematol 2011; 90: 917-931. https://doi.org/10.1007/s00277-011-1175-6

[18] MITSIADES CS, MITSIADES NS, MUNSHI NC, RICHARDSON PG, ANDERSON KC. The role of the bone microenvironment in the pathophysiology and therapeutic management of multiple myeloma: interplay of growth factors, their receptors and stromal interactions. Eur J Cancer 2006; 42: 1564-1573. https://doi.org/10.1016/j.ejca.2005.12.025

[19] CHAUHAN D, UCHIYAMA H, AKBARALI Y, URASHIMA $\mathrm{M}$, YAMAMOTO $\mathrm{K}$ et al. Multiple myeloma cell adhesioninduced interleukin-6 expression in bone marrow stromal cells involves activation of NF-kappa B. Blood 1996; 87: 11041112.

[20] LAUTA VM. A review of the cytokine network in multiple myeloma: diagnostic, prognostic, and therapeutic implications. Cancer 2003; 97: 2440-2452. https://doi.org/10.1002/ $\underline{\text { cncr. } 11072}$

[21] LENTZSCH S, CHATTERJEE M, GRIES M, BOMMERT K, GOLLASCH H et al. PI3-K/AKT/FKHR and MAPK signaling cascades are redundantly stimulated by a variety of cytokines and contribute independently to proliferation and survival of multiple myeloma cells. Leukemia 2004; 18: 1883-1890. https://doi.org/10.1038/sj.leu.2403486

[22] CHEUNG WC, VAN NESS B. The bone marrow stromal microenvironment influences myeloma therapeutic response in vitro. Leukemia. 2001; 15: 264-271. https://doi.org/10.1038/ sj.leu. 2402022

[23] HAO M, ZHANG L, AN G, MENG H, HAN Y et al. Bone marrow stromal cells protect myeloma cells from bortezomib induced apoptosis by suppressing microRNA-15a expression. Leuk Lymphoma 2011; 52: 1787-1794. https://doi.org/10.3 109/10428194.2011.576791

[24] VYHLIDALOVA I, UHERKOVA L, PLESCHNEROVA M, SPICKA I, BŘEZINOVA J et al. Characterization of a new human plasma cell leukemia cell line UHKT-944. Eur J Haematol 2015; 95: 352-360. https://doi.org/10.1111/ejh.12505

[25] KUZELOVA K, PLUSKALOVA M, BRODSKA B, OTEVRELOVA P, ELKNEROVA K et al. Suberoylanilide hydroxamic acid (SAHA) at subtoxic concentrations increases the adhesivity of human leukemic cells to fibronectin. J Cell Biochem 2010; 109: 184-195. https://doi.org/10.1002/jcb.22397

[26] MUNK PEDERSEN I, REED J. Microenvironmental interactions and survival of CLL B-cells. Leuk Lymphoma 2004; 45: 2365-2372. https://doi.org/10.1080/10428190412331272703

[27] MEADS MB, HAZLEHURST LA, DALTON WS. The bone marrow microenvironment as a tumor sanctuary and contributor to drug resistance. Clin Cancer Res 2008; 14: 2519-2526. https://doi.org/10.1158/1078-0432.CCR-07-2223

[28] GOTTLICHER M, MINUCCI S, ZHU P, KRAMER OH, SCHIMPF A et al. Valproic acid defines a novel class of HDAC inhibitors inducing differentiation of transformed 
cells. EMBO J 2001; 20: 6969-6978. https://doi.org/10.1093/ emboj/20.24.6969

[29] MARKS PA. Discovery and development of SAHA as an anticancer agent. Oncogene 2007; 26: 1351-1356. https://doi. org/10.1038/sj.onc. 1210204

[30] KITAZOE K, ABE M, HIASA M, ODA A, AMOU H et al. Valproic acid exerts anti-tumor as well as anti-angiogenic effects on myeloma. Int J Hematol 2009; 89: 45-57. https:// doi.org/10.1007/s12185-008-0226-9

[31] BAI LY, OMAR HA, CHIU CF, CHI ZP, HU JL et al. Antitumor effects of (S)- HDAC42, a phenylbutryate-derived histone deacetylase inhibitor, in multiple myeloma cells. Cancer Chemother Pharmacol 2011; 68: 489-496. https:// doi.org/10.1007/s00280-010-1501-Z

[32] KAISER M, ZAVRSKI I, STERZ J, JAKOB C, FLEISSNER $\mathrm{C}$ et al. The effects of the histone deacetylase inhibitor valproic acid on cell cycle, growth suppression and apoptosis in multiple myeloma. Haematologica 2006; 91: 248-251.

[33] SCHWARTZ C, PALISSOT V, AOUALI N, WACK S, BRONS $\mathrm{NH}$ et al. Valproic acid induces non-apoptotic cell death mechanisms in multiple myeloma cell lines. Int J Oncol 2007; 30: 573-382. https://doi.org/10.3892/ijo.30.3.573

[34] KAWAGOE R, KAWAGOE H, SANO K. Valproic acid induces apoptosis in human leukemia cells by stimulating both caspase-dependent and -independent apoptotic signaling pathways. Leuk Res 2002; 26: 495-502. https://doi. org/10.1016/S0145-2126(01)00151-5

[35] DAMIANO JS, CRESS AE, HAZLEHURST LA, SHTIL AA, DALTON WS. Cell adhesion mediated drug resistance (CAMDR): role of integrins and resistance to apoptosis in human myeloma cell lines. Blood 1999; 93: 1658-1667.

[36] XU FH, SHARMA S, GARDNER A, TU Y, RAITANO A et al. Interleukin-6-induced inhibition of multiple myeloma cell apoptosis: support for the hypothesis that protection is mediated via inhibition of the JNK/SAPK pathway. Blood 1998; 92: 241-251.

[37] XU F, GARDNER A, TU Y, MICHL P, PRAGER D et al. Multiple myeloma cells are protected against dexamethasone-induced apoptosis by insulin-like growth factors. Br J Haematol 1997; 97: 429-440. https://doi.org/10.1046/j.13652141.1997.592708.x

[38] CATLEY L, WEISBERG E, TAI YT, ATADJA P, REMISZEWSKI $S$ et al. NVP-LAQ824 is a potent novel histone deacetylase inhibitor with significant activity against multiple myeloma Blood 2003; 102: 2615-2622. https://doi. org/10.1182/blood-2003-01-0233

[39] DU HL, REN LM, CHEN H, ZHU Y, QI Y. Re-expression of p16 gene in the myeloma cell line U266 induced by synergy of sodium butyrate and 5-Aza-2'-deoxycytidine. Di Yi Jun Yi Da Xue Xue Bao 2002; 22: 981-984.

[40] RICHARDSON PG, SCHLOSSMAN RL, ALSINA M, WEBER DM, COUTRE SE et al. PANORAMA 2: panobinostat in combination with bortezomib and dexamethasone in patients with relapsed and bortezomib-refractory myeloma. Blood 2013; 122: 2331-2337. https://doi.org/10.1182/blood2013-01-481325

[41] SAN-MIGUEL JF, HUNGRIA VT, YOON SS, BEKSAC M, DIMOPOULOS MA et al. Panobinostat plus bortezomib and dexamethasone versus placebo plus bortezomib and dexamethasone in patients with relapsed or relapsed and refractory multiple myeloma: a multicentre, randomised, double-blind phase 3 trial. Lancet Oncol 2014; 15: 1195-1206. https://doi. org/10.1016/S1470-2045(14)70440-1

[42] GAO L, GAO M, YANG G, TAO Y, KONG Y et al. Synergistic Activity of Carfilzomib and Panobinostat in Multiple Myeloma Cells via Modulation of ROS Generation and ERK1/2. Biomed Res Int 2015; 2015: 902745. https://doi. org/10.1155/2015/459052

[43] ZHU S, DENMAN CJ, AND LEE DA. Valproic Acid Selectively Inhibits STAT3 Phosphorylation. Abstract 1720. 51th ASH Annual Meeting and Exposition. Dec 5, 2009. New Orleans, LA, accessed on Oct 22, 2016. https://ash.confex. com/ash/2009/webprogram/Paper20585.html

[44] SCUTO A, KREJCI P, POPPLEWELL L, WU J, WANG Y et al. The novel JAK inhibitor AZD1480 blocks STAT3 and FGFR3 signaling, resulting in suppression of human myeloma cell growth and survival. Leukemia 2011; 25: 538-550. https:// doi.org/10.1038/leu.2010.289

[45] HARVEY RD, LONIAL S. PI3 kinase/AKT pathway as a therapeutic target in multiple myeloma. Future Oncol 2007; 3: 639-647. https://doi.org/10.2217/14796694.3.6.639

[46] TABE Y, JIN L, TSUTSUMI-ISHII Y, XU Y, MCQUEEN T et al. Activation of integrin-linked kinase is a critical prosurvival pathway induced in leukemic cells by bone marrow-derived stromal cells. Cancer Res 2007; 67: 684-694. https://doi. org/10.1158/0008-5472.CAN-06-3166

[47] MITSIADES CS, MITSIADES NS, MCMULLAN CJ, POULAKI V, SHRINGARPURE R et al. Transcriptional signature of histone deacetylase inhibition in multiple myeloma: biological and clinical implications. Proc Natl Acad Sci USA 2004; 101: 540-545. https://doi.org/10.1073/pnas.2536759100

[48] LAVELLE D, CHEN YH, HANKEWYCH M, DESIMONE J. Histone deacetylase inhibitors increase p21(WAF1) and induce apoptosis of human myeloma cell lines independent of decreased IL-6 receptor expression. Am J Hematol 2001; 68: 170-178. https://doi.org/10.1002/ajh.1174 


\section{Supplementary Figure legends:}

\section{Supplementary Figure 1. Illustrative flow data of Annexin and PI staining.}

Picture shows illustrative dotplot of cells stained with Annexin V-Alexa488, detected in FITC channel. Control without propidium iodide (PI) is shown in the left figure (A), propidium iodide stained cells are presented in figure (B), PI signal was measured in PE channel. Gated areas present intact cells $(\mathrm{Q} 3)$, early apoptotic $(\mathrm{Q} 4)$ and late apoptotic $(\mathrm{Q} 2)$ cells. Selection of gates reflects the fact that a partial accumulation of PI accompanied the externalisation of phosphatidylserine in UHKT-944 cells. In late apoptotic/necrotic phases the intensity of PI fluorescence was higher.

A

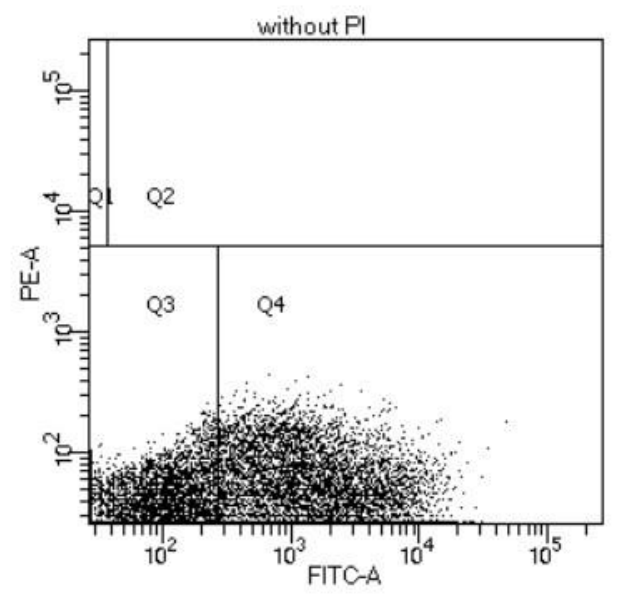

B

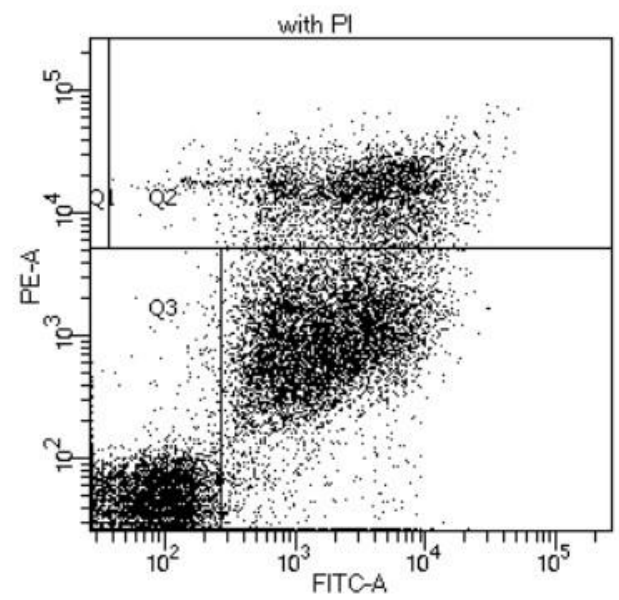

Supplementary Figure 2. Effect of VPA and SAHA to cell proliferation in presence of ECM proteins.

UHKT-944 cells were cultivated alone or with ECM components. Cells were incubated with appropriate concentrations of VPA and SAHA for 24 and 48 hours. Cell proliferation was measured using alamarBlue assay. The results represent mean \pm standard deviation of three independent experiments. 
$\square 24$ hours + ECM $\square 24$ hours $\square 48$ hours + ECM $\square 48$ hours

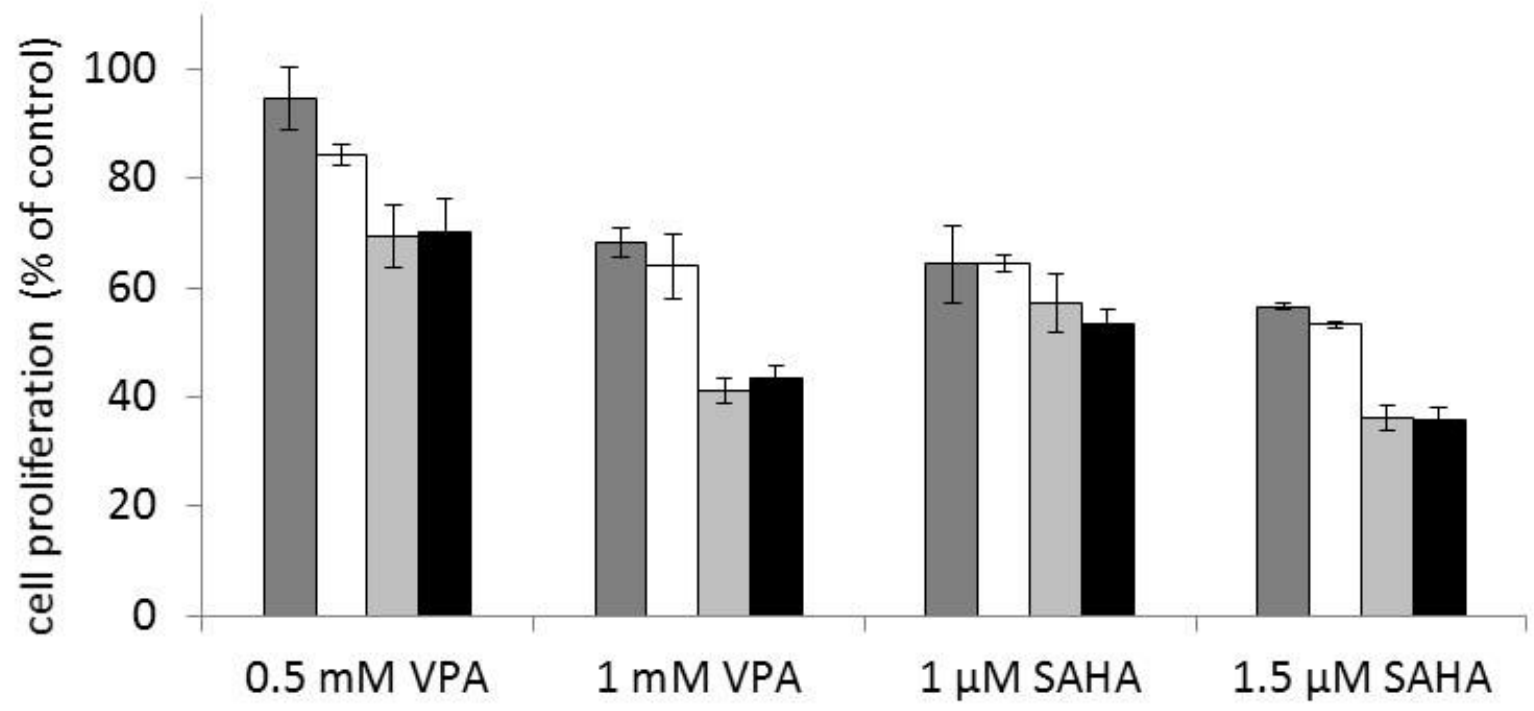

Supplementary Figure 3. Illustrative histograms of cell cycle phases distribution of UHKT-944 cells untreated and treated with 1 mM VPA.

In the histogram of untreated cells (A) the phases of cell cycle are shown - sub-G1, G0/G1, S and G2/M. The amount of cells in sub-G1 phase increased in cells treated with $1 \mathrm{mM}$ VPA (histogram B).

A

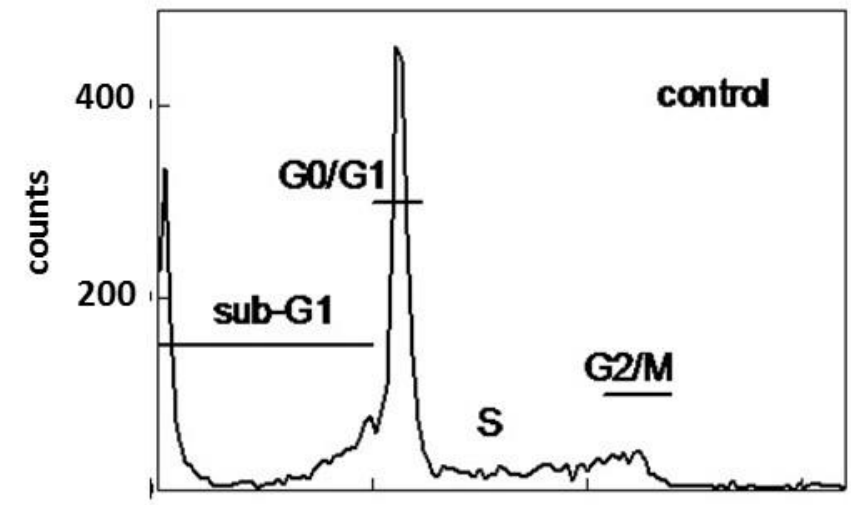

PE-A

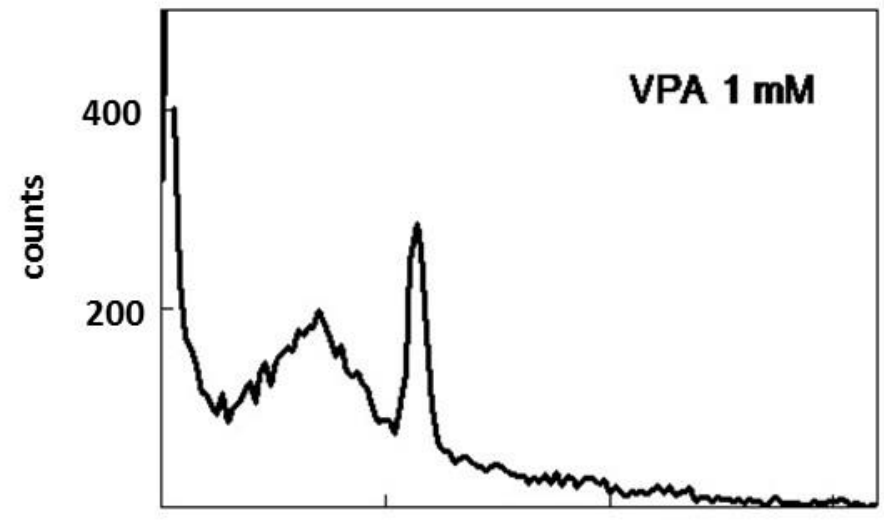

PE-A 